\title{
The Role of Cassava in Improving Rural Food Security and Income among Farmers in Abia State, Nigeria
}

\author{
Uchechi Apu and Ebelenna Oragwam \\ Department of Rural Sociology and Extension \\ Michael Okpara University of Agriculture \\ Umudike, Umuahia, Abia State, Nigeria
}

\begin{abstract}
This study examined the role of cassava in improving food security and income among farmers in Abia State, Nigeria. The study was conducted in Umuahia South Local Government Area (LGA) of Abia State, Nigeria. Multi-stage random sampling procedure was used in selecting a total of one hundred and forty four (144) cassava farmers, which constituted the sample size for the study. Simple random sampling procedure was used in selecting six out of the eight cells in the area. Three rural communities were randomly selected from each of the six cells, giving a total of eighteen rural communities. Eight respondents were randomly selected from the list of cassava farmers in each of the eighteen rural communities, giving a total of one hundred and forty four respondents on the whole. Data collection from the respondents was facilitated by the use of structured questionnaire. Data analysis employed simple descriptive statistics such as frequency counts and percentages as well as multiple regression analysis. Results showed that majority of the respondents (56.30\%) were males while (43.80\%) were females.. Results also revealed that majority of the respondents (54.20\%) were married. Majority of respondents (61.10\%) were within the age range of 31-50 years. Majority of the respondents in the area (67.15\%) could read and write and can therefore exploit various sources of information to boost their cassava production enterprise. Regression results of the determinants of the level of income of the respondents revealed that five out the seven coefficients of explanatory variables were significant, meaning that any change in any of these variables resulted in a change in the income of the respondents. Positive relationships were established for farm size, farm input(s), household size and extension visit. However, a negative relationship was established for age. Furthermore, the analysis of the determinants of factors influencing the level of food security among cassava farmers in the area revealed that positive relationships were established for extension visit, and farm input(s) ,while a negative relationship was established also for age. The positive relationship indicates that an increase in any of the explanatory variables resulted in increase in food security in terms of cassava output from farmers. The conclusion is that massive cassava cultivation is capable of significantly improving rural food security and income among farmers in the study area and the county at large. It is therefore recommended that relevant farm inputs should be provided for farmers at the appropriate time and should also be subsidized. Also, more extension agents should be employed in order to improve upon the number of visits of extension personnel to farmers in the state.
\end{abstract}




\section{INTRODUCTION}

Food security is said to exist when all people, at all times, have physical and economic access to sufficient, safe and nutritious food to meet their dietary needs and preferences for an active and healthy life (Ogbuagu, 2004). Furthermore, Ogbuagu, (2004) reported the United Nations Children's fund (UNICEF) and the Federal Republic of Nigeria (1990) to have described food security as involving the "ensuring of staple food availability at the average household throughout the year, improved nutritional status of children and mothers and enhanced cash income for women..." From the foregoing definitions, it may be concluded that the determinants of food security, whether at the household, national or global levels, include availability of staple food(s) throughout the year, improved nutritional status of the people (especially farmers), among others.

Cassava is one of the major staple food crops which is widely grown in Nigeria. Akoroda and Terri (2004) reported that cassava was considered by the rural households as their most important food crop. It is consumed in various processed forms such as garri, chips/ flour, fermented paste, starch e.t.c (Anuebunwa, Ezedinma, Ugwu, Asumugha and Nnodu, 1998). Some of the inherent characteristics which make cassava (as a food crop) attractive, especially to the small holder farmers in Nigeria are that it is rich in carbohydrate, especially starch and consequently has a multiplicity of end users. Furthermore, it is available all the year round, making it preferable to other more seasonal crops such as grains, peas/beans and other crops of food security ( Akoroda and Terri, 2004).

Although cassava is one of the most important staple food crops of Nigeria, the crop used to be known as a subsistence crop as well as a women's crop. Okorji (1983) reported that in the Abakaliki area of South-East Nigeria, women owned more Cassava fields than men and concluded that cassava is a woman's crops. However, this crop (cassava) is now known to have blossomed into an all-important income generating crop. Nzekwe and Afolami (2001) reported that currently, cassava cultivation has become an income generating activity. They stated that this enhanced status of the crop is as a result of increased demand for cassava products outside the rural communities (Ikpi, Gabrenskel, Ezuma and Ekpere, 1986) as well as the realization of the attainment of self sufficiency in food production (Kwatia, 1986).

Media reports are replete with global food crisis currently sweeping across the globe. This state of affair portends grave threats to the food security of many households, nations and the world at large. It is against this background that this study is geared towards assessing and /or reviewing the role of cassava in improving rural food security and income among farmers in Abia State, Nigeria.

The study specifically intends to ascertain the socio-economic characteristics of rural (cassava) farmers in the study area; determine the level of income of the cassava farmers and determine the factors influencing food security of cassava farmers in the study area.

\section{METHODOLOGY}

The study was conducted in Umuahia South Local Government Area (LGA) of Abia State, Nigeria. Umuahia South is located in Umuahia Agricultural zone of the state. Umuahia South LGA consists of one extension block and eight cells. Farming is the major or primary occupation of the people. Cassava cultivation is prominent among farmers in the area. 


\section{Journal of Agricultural Extension}

Vol. 13 (1) June, 2009

\section{Population and Sampling Procedure}

The population of the study was all cassava farmers in the study area. Multi-stage random sampling procedure was used in selecting a total of one hundred and forty four (144) cassava farmers, which constituted the sample size for the study. Six out of the eight extension cells in the study area were randomly selected using simple random sampling technique. Three rural communities were randomly selected from each of the six cells, giving a total of eighteen (18) rural communities. Eight (8) cassava farmers were randomly selected from the list of cassava farmers in each of the eighteen rural communities, giving a total of one hundred and forty four respondents. These constituted the sample size for the study.

\section{Data Collection and Analysis}

Data collection from the respondents was with the aid of structured questionnaire, which was validated for the purpose. Data analysis made use of simple descriptive statistics such as frequency counts, percentages and multiple regression analysis was also used to analyse the effect of cassava output on level of food security and income. The implicit form of the model was specified as follows:

\begin{tabular}{|c|c|c|}
\hline Z & $=$ & $\left(\mathrm{X}_{1}, \mathrm{X}_{2}, \mathrm{X}_{3}, \mathrm{X}_{4}, \mathrm{X}_{5}, \mathrm{X}_{6}, \mathrm{X}_{7}, \mathrm{ei}\right)$ \\
\hline $\mathrm{F}$ & $=$ & $\left(\mathrm{X}_{1}, \mathrm{X}_{2}, \mathrm{X}_{3}, \mathrm{X}_{4}, \mathrm{X}_{5}, \mathrm{X}_{6}, \mathrm{X}_{7}, \mathrm{ei}\right)$ \\
\hline Z & $=$ & level of food security (output of cassava \\
\hline $\mathrm{X}_{1}$ & $=$ & Age of farmer in years \\
\hline $\mathrm{X}_{2}$ & $=$ & Educational level of farmer \\
\hline$X_{3}$ & $=$ & Household size \\
\hline $\mathrm{X}_{4}$ & $=$ & Farm input $(\mathrm{N})$ \\
\hline$X_{5}$ & $=$ & Farming experience \\
\hline $\mathrm{X}_{6}$ & $=$ & Farm size \\
\hline $\mathrm{X}_{7}$ & $=$ & Output of cassava $(\mathrm{N})$ \\
\hline ei & $=$ & Error term \\
\hline Y & $=$ & Level of income $(\mathrm{N})$ \\
\hline $\mathrm{X}_{1}$ & $=$ & Age of farmer in years \\
\hline $\mathrm{X}_{2}$ & $=$ & Educational level of farmer \\
\hline$X_{3}$ & $=$ & Household size \\
\hline $\mathrm{X}_{4}$ & $=$ & Farm input (N) \\
\hline$X_{5}$ & $=$ & Farming experience \\
\hline $\mathrm{X}_{6}$ & $=$ & Farm size \\
\hline $\mathrm{X}_{7}$ & $=$ & Output of cassava $(\mathrm{N})$ \\
\hline
\end{tabular}


The exponential functional form, which was explicitly expressed as

Log $Y_{2}=b_{0}+b_{1} X_{1}+b_{2} X_{2}+b_{3} X_{3}+b_{4} X_{4}+b_{5} X_{5}+b_{6} X_{6}+b_{7} X_{7} \ldots+e$ provided the best fit for explaining the determinants of the level of income of the respondents. In like manner, the exponential functional form also provided the best fit for analyzing the determinants of factors influencing the level of food security. This was explicitly expressed as

$\log Y 1=b_{0}+b_{1} X_{1}+b_{2} X_{2}+b_{3} X_{3}+b_{4} X_{4}+b_{5} X_{5}+b_{6} X_{6}+b_{7} X_{7} \ldots+e$

\section{RESULTS AND DISCUSSION}

The socio-economic characteristics of the respondents are presented in Table 1. Results showed that majority of the respondents $(56.30 \%)$ were males while $(43.80 \%)$ were female. This disagrees with Okorji (1983), who stated that in Abakiliki area of South-east Nigeria women owned more cassava fields than men and that cassava was a women's crop. Cassava cultivation in Nigeria today is therefore no longer a female dominated enterprise.

Table I also revealed that majority of the respondents $(54.20 \%)$ were married, implying that cassava cultivation (production) in the study area is more in the hands of married people. Furthermore, results showed that majority of the respondents $(61.10 \%)$ were within the age range of 31-50 years, indicating that majority of the Cassava farmers in the area were within the active and innovative years. The implication is that these farmers are active and energetic and they are likely not to leave anything to chance towards making a success of their cassava farming enterprise. The mean age of the farmers is 28.8 years.

Farmers in the study area were found to have varying levels of formal education. Only about $12.50 \%$ of the respondents had no formal education. A reasonable proportion of the respondents $(34.41 \%)$ had complete primary education. However, majority of the respondents $(67.15 \%)$ could read and write and could therefore exploit various sources of information that could help promote their cassava farming business. 
Journal of Agricultural Extension

Vol. 13 (1) June, 2009

TABLE 1: Distribution of Farmers by their Socio-Economic Characteristics

\begin{tabular}{|c|c|c|c|}
\hline Variables & Frequency & $\%$ & \\
\hline \multicolumn{4}{|l|}{ Sex } \\
\hline Male & 81 & 65.30 & \\
\hline Female & 63 & 43.80 & \\
\hline \multicolumn{4}{|l|}{ Marital Status } \\
\hline Single & 35 & 24.30 & \\
\hline Married & 78 & 54.20 & \\
\hline Divorced & 14 & 9.70 & \\
\hline Widowed & 17 & 11.80 & \\
\hline \multicolumn{4}{|l|}{ Age } \\
\hline $21-30$ years & 14 & 9.70 & \\
\hline $31-40$ years & 35 & 24.307 & \\
\hline $41-50$ years & 53 & 36.80 & 61.10 \\
\hline $51-60$ years & 30 & $20.80^{J}$ & \\
\hline 60 and above & 12 & 8.33 & \\
\hline \multicolumn{4}{|c|}{ Level of Formal Education } \\
\hline No formal education & 18 & 12.50 & \\
\hline Primary (incomplete) & 28 & 19.44 & \\
\hline Primary (complete) & 51 & 34.41 & \\
\hline Secondary (Incomplete) & 10 & 6.94 & \\
\hline Secondary (Complete) & 21 & 14.90 & \\
\hline OND/NCE/HND & 12 & 8.33 & \\
\hline B.Sc./B/A./B/ Agric & 04 & 2.77 & \\
\hline \multicolumn{4}{|l|}{ Farming Experience } \\
\hline Less than 6 years & 12 & 8.33 & \\
\hline $6-10$ years & 24 & 16.66 & \\
\hline $11-15$ years & 47 & 32.63 & \\
\hline $16-20$ years & 20 & 13.88 & -46.51 \\
\hline $21-25$ years & 14 & 9.72 & \\
\hline 26 and above & 27 & 18.75 & \\
\hline \multicolumn{4}{|l|}{ Household Size } \\
\hline $1-5$ & 60 & 41.66 & \\
\hline $6-10$ & 74 & 51.38 & \\
\hline $11-15$ & 07 & 4.86 & \\
\hline 16 and above & 03 & 2.03 & \\
\hline
\end{tabular}

Source: Field Survey. 2008

Table 1 also showed that farmers in the study area were very well experienced, as majority of the respondents have varying years of farming experience spanning from 11-25 years. This result agrees with Apantaku et.al (2004) who reported that more than two thirds of framers in Ogun state had at least 10 years of farming experience. 
Results also revealed that majority of the respondents $(51.38 \%)$ have household sizes ranging between 6-10 people. This distribution indicates that the household size of the respondents is generally high. With large household sizes, most of the farm families are likely to source some of their farm labour from within their households.

\section{Determinants of Level of Income of Respondents}

A multiple regression analysis was employed to examine the determinants of the level of income of cassava farmers in the study area and the results are presented in Table 2. The results reveal that five out of seven coefficients of explanatory variables are significant, which means that any change in any of these factors could result in a change in the income of the respondents. Positive relationship is established for farm size, farm inputs, household size and extension visits.

However, a negative relationship is established for age. The positive relationship shows that an increase in any of the explanatory variables (regressors) will increase income while the negative relationship implies that an increase in the regressors will decrease the income of the farmers in the area. Thus, from the result in Table 2, it means that the greater the farm size cultivated by a farmer the higher the income derived from the farm. Also, the greater the farm inputs (such as improved planting materials and fertilizers) used in the farm, the higher the income earned from the farm. In like manner, the larger the household size and the greater the extension visits to farmers, the more income earned by such farmers. On the other hand, the higher the age of the farmer, the lower the income earned from their farming activities. This means that younger farmers earn more income from their farming endeavours including cassava farming. The coefficient of farm size was significant at 5 percent level while those of age, farm input, household size and extension visit were significant at $1 \%$ level.

In general $58.5 \%$ (approximately 59 percent) of the variations in income of the cassava farmers in the study area is explained by the explanatory variables included in the regression model as indicated by the coefficient of determination $\left(R^{2}=0.585\right)$. The lower adjusted $R_{-}{ }^{2}$ of 0.359 connotes that the inclusion of any additional variable may not necessarily improve the regression results. 
Journal of Agricultural Extension

Vol. 13 (1) June, 2009

TABLE 2: Regression Results of Determinants of Level of Income of Cassava Farmers

\begin{tabular}{lc}
\hline Variable & Coefficients \\
\hline Constant & 13.230 \\
Farm size & $(18.715)^{\star * *}$ \\
& 0.212 \\
Age & $(1.797)^{\star * *}$ \\
& -0.052 \\
Farm input & $(-4.727)^{\star * *}$ \\
Household size & $2.16 \mathrm{E}-005$ \\
& $(3.665)^{\star * *}$ \\
Output & 0.035 \\
& $(3.182)^{\star * *}$ \\
Education & $9.66 \mathrm{E}-006$ \\
& $(0.193)$ \\
Extension Visit & 0.13 \\
& $(0.527)$ \\
Farming experience & 0.447 \\
$R^{2}$ & $(1.913)^{\star * *}$ \\
R-2 & -0.017 \\
F-ratio & $(-1.145)$ \\
\hline
\end{tabular}

*** Coefficients, significant at 1\% level

** Coefficients significant at $5 \%$

Determinants of Factors Influencing the Level of Food Security Among Cassava Farmers in the Study Area

A multiple regression analysis was used to examine the factors influencing the level of food security (output of cassava) among farmers in the study area and the results are presented in Table 3. The results reveal that three out of the seven coefficients of explanatory variables were significant, which means that any change in any of these variables resulted in a change in the level of food security (output) among farmers in the study area. Positive relationship was established for extension visit and farm inputs, while a negative relationship was established for age. The positive relationship indicates that an increase in any of the explanatory variables will lead to increase in food security (output) of cassava among farmers in the study area. The negative relationship on the other hand shows that an increase in the explanatory variables will result in decrease in the level of food security (output) of cassava among farmers in the area. Thus, the result in Table 3 means that as extension visit to farmers increases as well as farm inputs, so do the level of food security reflected in output of cassava among farmers in the study area. 
However, although age was negatively related to the level of food security (output) of cassava, it was significant at $5 \%$ level. The implication is that as age increases, food security (output) among cassava farmers decrease. The coefficient of extension visit to farmers is significant at $5 \%$ level, while that of farm input was significant at $10 \%$ level. In general 49.9 approximately 50 percent of the variations in the level food security (output) among cassava farmers in the study area is explained by the explanatory variables included in the regression model as indicated by the coefficient of determination $\left(R^{2}=0.499\right)$.

TABLE 3: Regression Results of Factors Influencing Level of Food Security (Cassava Output) Among Farmers in the Study Area

Variable(s) Coefficient

Constant

5.475

Age

$(7.595)^{\star * *}$

$-0.020$

$(-2.222)^{\star *}$

Education

0.024

Household size

(0.970)

$-0.038$

$(-0.721)$

Farming experience

0.019

$(0.217)$

Farm input

9.96E-006

$(1.638)^{*}$

Farm size

$-0.054$

Extension visit

$(-0.531)$

0.512

$\mathrm{R}^{2}$

$(2.127)^{* *}$

$\mathrm{R}^{2}{ }^{2}$

0.499

F-Ratio

0.205

1.933

\footnotetext{
*** Coefficient significant at 1\% level

** Coefficient significant at 5\% level

* Coefficient significant at 10\% level
}

\section{CONCLUSION AND RECOMMENDATIONS}

Cassava, one of the most important staple food crops grown in Nigeria, is no longer a subsistent crop and is no longer a women's crop. Majority (56.30\%) of the cassava farmers in the study area are males. Majority (54.20\%) of the farmers were married people, implying that cassava production in the study area is in the hands of married people. 


\section{Journal of Agricultural Extension}

Vol. 13 (1) June, 2009

Furthermore majority of the farmers $(61.10 \%)$ were within the active and innovative years (31-50 years). This implies that these active and innovative farmers will maximize all resources at their disposal toward making a success of their cassava farming enterprise. Majority of the farmers in the study area $(67.15 \%)$ could read and write and are therefore able to exploit various sources of information to promote and improve their cassava farming business.

Majority of the farmers $(46.51 \%)$ were found to have varying years of cassava farming experience spanning from 11 to 12, years. The result agrees with Pancake et.al (2004) who reported that more than two thirds of farmers in Ogun State have at least 10 years of farming experience. Also majority of the framers $(51.38 \%)$ have household sizes varying between $6-10$ persons. This indicates that household sizes in the study area are generally high, and this is likely to increase the chances of sourcing farm labour from the immediate household.

Five out of seven coefficients of explanatory variable in the regression model are significant, meaning that any change in any of the specified variables resulted in a change the income of cassava farmers in the area. Farmer size, fame input(s), household size and extension visits were found to be positively related to the income of cassava farmers in the study area.

Also, three out of the seven coefficients of explanatory variables included in the regression model for factors influencing the level of food security (cassava output) were significant. This means that changes in any of these variables resulted in changes in the level of food security among farmers in the study area. It was concluded therefore that cassava is capable of significantly improving rural food security and income among farmers in the state in particular and the country at large.

It is, therefore, recommended that relevant farm inputs (including improved planting materials as well as fertilizers) should be provided for farmers at the appropriate time and should also be subsidized. This is with a view to enabling farmers maximize the incremental benefits accruing from the use (adoption) of such inputs on their farms. Also more extension agents (EAS) should be employed in order to improve on the number of visits of the extension personnel to farmers.

\section{REFERENCES}

Akoroda, M. O. and Terri, J. M. (2004). "Food Security and Diversification in SADC Countries Approach. A case study of Western Nigeria Cassava farmers.' Indian Journal of Agricultural Economics 27(2) 56-66.

Apantaku, S. O., J.M Awotunde, D. A. Adegbite, and E. A. Ajayi (2004). "Feasibility of Private.

Integrated Agricultural Extension". A Paper presented at the 9th National Conference of Agricultural Extension Society of Nigeria AESON) held at the Conference Centre, Obafemi Awolowo University lle-Ife, P.32.

Ogbuagu, S. C. (2004). "Gender, Population and Environmental Issues". Ark Publishers, Owerri, pp. 97-98.

Anuebunwa, F. O. C, C. Ezedinma, B.O Ugwu, G. N. Asumugha and E. C. Nnodu (1998). "A Research Report on the Extent of Adoption of NRCRI- Developed Technology: Cassava Varieties (NR8082, NR8083 and TMS 4 (2) 1425 in Abia, Anambra and Delta States of Nigeria. Submitted to NARP Management, Abuja. NRCRI, Umudike.

Ikpi, A. E.Gabreneskel T, N. D. Ezumah and Ekpere J. A. (1986). "Cassava: A Crop for household Food security. A 1986 situation Analysis of Oyo Local Government Area, Nigeria, Ibadan, Nigeria, IITA UNICEF Report. 
Kwatia, T. T. (1986). "Rural Cassava Processing and Utilization Centres". Ibadan Nigeria.

International Institute of Tropical Agriculture. IITA-UNICEF Report.

Nzekwe, L. S. O. and C. Afolami (2001). "Technology Adoption of Improved Practices by Small Scale Cassava Farmers in Agriculture Development Programme (ADP) Zones of Ogun State". Proceeding of the 35th Annual Conference of the Agricultural Society of Nigeria, held at the University of Agriculture, Abeokuta, Nigeria, p.331.

Okorji, E. C. (1983). "Consequence for Agricultural Productivity of Crops of Ebonyi State. M. Sc. Thesis of the Department of Agriculture Economics, University of Nigeria, Nsukka, Nigeria. 